\title{
ЕКОНОМІЧНА TEOPIЯ
}

\author{
Olga Nosova, Tetiana Nosova \\ V.N. Karazin Kharkiv National University \\ 4 Svobody Sq., 61022, Kharkiv, Ukraine \\ E-mail: olgano59@gmail.com, tasya.n@gmail.com \\ ORCID: https://orcid.org/0000-0002-5638-6294, https://orcid.org/0000-0003-1757-4505
}

\section{THE INNOVATIONS EFFECTS AT COMPANY'S LABOUR PRODUCTIVITY}

The paper deals with the analysis of innovations effects on labour productivity, work quality, work contracts. Innovations are the basic factors in the growth of labour productivity. The innovations growth provides the release of labor force in low-tech sectors of the economy, the redistribution of workers in favor of high -tech sectors of the economy with high value added, and a major source of improving the welfare of the population and development of society. The methodology includes the interdisciplinary approach application based on institutional analysis, human resource management and comparative economics methods. The systematization of the basic approaches including systemic innovation system, the permanent organizations, innovation diffusion concept and etc. expand the object of study, and allows finding new directions in the study of the interdependence between innovations and labour productivity. The study of Ukrainian economic performance indicators of public R\&D expenditures, innovation expenditures, employment in medium to high-tech manufacturing and high-tech services confirms decrease in public spending. The recent studies emphasize the main transformation in the world of work in terms of the labour market, social dialogue, and conditions of work, wages and incomes, and effects on the middle class. The strong institutions play significant role in the process of knowledge accumulation, creation wellfunctioning market system, institutional and infrastructure development. They are fully consistent with high employment and dynamic labour market functioning. The information technologies development contributes into the average annual growth of labour productivity in a range of the developed countries. The directions of preconditions for innovative development and the formation of partnerships and links between education, business, science, and innovation are proposed.

Keywords: labour productivity, innovations, labour costs, work contracts.

JEL Classification: J08, J21, J24.

О.В. Носова, Т.Ю. Носова

Харківський національний університет імені В. Н. Каразіна пл. Свободи, 4, м. Харків, 61022, Україна

E-mail: olgano59@gmail.com, tasya.n@gmail.com

ORCID: https://orcid.org/0000-0002-5638-6294, https://orcid.org/0000-0003-1757-4505

\section{ЕФЕКТИ ІННОВАЦІЙ НА ПРОДУКТИВНІСТЬ ПРАЦІ В КОМПАНІЇ}

У статті розглядаються ефекти впливу інновацій на продуктивність праці, якість роботи та трудові контракти. Інновації - це основні фактори зростання продуктивності праці. Збільшення інновацій забезпечує вивільнення робочої сили у низько технологічних галузях економіки, перерозподіл робітників на користь високотехнологічних секторів економіки з високою частиною доданої вартості, а також головного джерела покращення добробуту населення та розвитку суспільства. Методологія дослідження включає застосування міждисциплінарного підходу, заснованого на використанні інституціонального аналізу, управління людськими ресурсами та методу економічної компаративістики. Систематизація основних підходів, включаючи системну інноваційну систему, постійну організацію, концепцію дифузії інновацій тощо розширює об'єкт дослідження та дозволяє знаходити нові напрямки у вивченні взаємозалежності між інноваціями та продуктивністю праці. Дослідження економічних показників державних витрат на НДДКР, витрат на інновації, зайнятість у виробництві середніх та високотехнологічних технологій та високотехнологічних послуг підтверджує зменшення державних витрат на НДДКР. Останні дослідження підкреслюють основну трансформацію у світі праці з точки зору ринку праці, соціального діалогу та умов праці, заробітної плати та доходів та впливу на середній клас.Сильні інститути відіграють значну роль у процесі накопичення знань, створенні добре функціонуючої ринкової системи, розвитку інституцій та

๑ Nosova O., Nosova T., 2019 
інфрраструктури. Вони повністю забезпечують високу зайнятість та динамічне функціонування ринку праці. Розвиток інформаційних технологій сприяє середньорічному зростанню продуктивності праці в цілому в країнах, що розвіваються. Запропоновано напрямки передумов інноваційного розвитку та формування партнерських відносин та зав'язків між освітою, бізнесом, наукою та інноваціями.

Ключові слова: продуктивність праці, інновації, витрати на оплату праці, трудові контракти.

JEL Classification: J08, J21, J24.

О.В. Носова, Т.Ю. Носова

Харьковский национальный университет имени В. Н. Каразина

пл. Свободы, 4, г. Харьков, 61022, Украина

E-mail: olgano59@gmail.com, tasya.n@gmail.com

ORCID: https://orcid.org/0000-0002-5638-6294, https://orcid.org/0000-0003-1757-4505

\section{ЭФФЕКТЫ ИННОВАЦИЙ НА ПРОИЗВОДИТЕЛЬНОСТЬ ТРУДА В КОМПАНИИ}

В статье рассматриваются эффекты влияния инноваций на производительность труда, качество работы и трудовые контракты. Инновации рассматриваются в качестве основного фактора роста производительности труда. Увеличение инноваций обеспечивает высвобождение рабочей силы в низко технологичных отраслях экономики, перераспределение рабочих в пользу высокотехнологичных секторов экономики с высокой долей добавленной стоимости, а также главного источника улучшения благосостояния населения и развития общества.Методология исследования включает применение междисциплинарного подхода, основанного на использовании институционального анализа, управления человеческими ресурсами и метода экономической компаративистики. Систематизация основных подходов, включая системной инновационной системы, постоянной организации, концепции диффузии инноваций и т.д., расширяет объект исследования и позволяет находить новые направления в изучении взаимозависимости между инновациями и производительностью труда. Изучение экономических показателей взаимозависимости государственных расходов и НИОКР, затрат на инновации, занятости в секторах производства средних и высокотехнологичных технологий и высокотехнологичных услуг подтверждает уменьшение доли государственных расходов на НИОКР. Современные исследования подчеркивают, что основу трансформации в сфрере труда обеспечивает развитие рынка труда, социального диалога и условий труда, заработной платы и доходов, а также влияния на средний класс.Сильные институты играют значительную роль в процессе накопления знаний, в создании хорошо функционирующей рыночной системы, развитии институтов и инфрраструктуры. Они полностью обеспечивают высокую занятость и динамичное функционирование рынка труда.Развитие информационных технологий способствует в среднем ежегодному росту производительности труда в развитых странах. Предложены направления предпосылок инновационного развития и формирования партнерских отношений и взаимосвязей между образованием, бизнесом, наукой и инновациями.

Ключевые слова: производительность труда, инновации, затраты на оплату труда, трудовые контракты.

JEL Classification: J08, J21, J24.

Statement of the problem. The article analyses the innovations effects on labour productivity, work quality, and work contracts. The spread of innovations and its application in high-tech sectors stimulate labour productivity growth, reduction old working places with low productivity and creation new industries with high value added products. The study aims to add to existing body of knowledge and to provide proposals for improvement of the legislative and the regulatory framework, the standards, the methods of calculation and the measurement of the labour productivity.

The innovation system concept has come to play a major role in efforts to shape public policies to better support innovation and economic growth (Lundwall, 2007). The innovations penetrate as a concept, as institutions, as creativity, channeled through temporary and permanent organisations, shaping markets and dialoguing with entrepreneurship, and as embedded in places and networks (Bathelt et al., 2017). The innovation policy supports innovation - diffusion, analyses the current knowledge phenomenon, and explores important challenges facing contemporary societies (Fagerberg, 2007).

Technological progress leads to higher productivity and economic growth, improves working conditions and wages, but it can also result in more rapid changes to firms and industries. The policy of enhancing innovation growth in Ukraine will lead to the creation new products; as a result stimulate production, and emergence new workplaces. The information technology boom has 
significant impact on labour force in favour of skilled labour increase with higher productivity comparing with unskilled labour.

The literature review demonstrates that without complementary investments, it will not be possible to fully benefit from the advantages of ICT capital for productivity growth. The preconditions for innovative development are human capital investment, education, and institutional settings. The formation of partnerships and links between education, business, science, and innovation can contribute to stimulating the demand for labor.

The development of rules, norms, and institutions in the society provide the basis for social dialogue in society concerning conditions for labour contracts, wage, regulatory framework, management and etc. Innovations stimulate labour productivity increase and result in the share of skilled labour rise and decrease of unskilled labour. The labour legislation improvement, elimination regulatory barriers for business, development of retraining programs direct labour productivity increase, and create incentives for workers.

Analysis of recent studies and publications. Innovation is regarded as a basic driving force in the process of narrowing gaps with developing countries in global economy. Innovation is considered as important precondition towards a transition into self-sustaining innovation led - growth economy. Effective innovation system includes firms, research centers, R\&D institutions which provide new goods creation, new processes and new knowledge.

The economic analysis of recent studies draws attention to a number of works considering direct and indirect innovation effects on labour productivity. An economic model ensuring a decent pay of its balanced formation (Kulikov, 2008) based on innovations rise. It leads to investment, value added, labour productivity, savings and demand increase. The upsurge in wages leads to higher demand, and, consequently, to the creation new workplaces. Bogliciano, Pianta (Bogliciano \& Pianta, 2009) make an analysis of economic performances in European industries. Authors explain the results of different innovation models, with strong specificities of the four revised Pavitt classes (i.e. "Science Based industries", "Scale and Information Intensive industries", "Specialised Suppliers industries" and "Suppliers Dominated industries"). Scientists proposed policies aiming at greater labor productivity growth may have to take into account the different mechanisms resulting from technological and cost competitiveness strategies. These strategies have the different relevance in industry groups. Preenen et al. (Preenen et al., 2015) suggest that internal labour flexibility practices benefit both labour productivity and innovation performance of companies. Researchers should make efforts to introduce new processes. If innovation and labour productivity are considered key to longterm survival, firms it means that policymakers should consider internal labour flexibility practices.

Dykha et al. (Dykha et al., 2017) claim the necessity of the basic principles fulfilment of the investment-innovation strategy. In order to achieve the goals of effective implementation such policy and obtain the results for ensuring labor productivity growth authors propose the priorities for public finance allocation, measures enhancing the development of venture capital and high-tech production stimulation. Innovation policy needs to be tailored to the position of Ukraine relative to the technology frontier because the institutions and policies that support "locally new" innovation through imitation, adoption and adaptation are not necessarily the same as those that favour "globally new", leadingedge innovation. Innovation activities in countries behind the technology frontier, such as Ukraine, focus mainly on the adaptation of machinery, equipment and software. The share of expenditure on machinery, equipment and software in total innovation expenditure in Ukraine is within the normal range for the EU new member States (Majcen et al, 2009).

Matteo et al. (Matteo et al. 2012) make research of labour productivity growth and ICT capital development of a sample of 14 OECD countries between 1995 and 2005. Authors receive overall results which indicate that capital accumulation was the main driving force of labour productivity growth. This study also found that ICT capital seems to produce an opposite effect on labour productivity growth: an increase through capital accumulation and a decrease through technological change. The results prove that without complementary investments, it will not be possible to fully benefit from the advantages of ICT capital for productivity growth.

Recent studies in labour economics underline the main transformation in the world of work over the last 20 years in terms of the labour market, social dialogue, and conditions of work, wages and incomes, and effects on the middle class (Vaughan-Whitehead et al., 2016). Strong institutions are not only 'the building blocks of just societies' but can be, if well designed, fully consistent with high employment and dynamic economies (Berg, 2015). The information technologies contribute into the 
average annual growth of labour productivity in a range of countries. The impact of IT on the system transformation of social labour relations defines by a set of parameters (Grishnova \& Kostenko, 2014). The following section emphasizes the importance of innovations and effective national strategy, institutions setting, enforcing labor productivity growth and overcoming backwardness and economic instability of the country.

Statement of the objectives of the article. The article deals with the analysis of the effects of innovations at company's labour productivity. The methodology includes the interdisciplinary approach application based on institutional analysis, human resource management and comparative economics methods. The systematization of the basic approaches including systemic innovation system, the permanent organizations, innovation diffusion concept and etc. expand the object of study, and allows finding new directions in the study of the interdependence between innovations and labour productivity.

Presentation of the basic material. The study of the Ukrainian labour market demonstrates that it is dynamically developed, but it isn't homogeneous. It distinguishes with the following peculiarities: cheap labour force, lowest minimum wage, high voluntary unemployment, misbalance of demand and supply of labour force, absence motivation for workers and etc. Unemployment rate in Ukraine calculated as percentage to the economically active population aged $15-70$ is $8,8 \%$ in 2018, for European Union countries - aged 15-74 equals 6,8 \% (Economic Activity of Population in Ukraine 2018, 2019). This indicator demonstrates the existence of the deep social economic problems at the labour market, especially high unemployment rate at the group from 18 to 28 ages workers. The number of unemployed people reached 1.6 million. The unemployment rate, by the ILO measure, was $9.0 \%$, and among people of working age it was $9.4 \%$ of the economically active population. Among young people aged up to 25 years, the unemployed rate was twice as much as the national average $-21.8 \%$ of the economically active population. The unemployment rate in urban areas was $8.9 \%$ and $9.2 \%$ in rural areas. Among men, the figure was $9.9 \%$ and among women $8.0 \%$. The study of the State Statistics Service shows that, the real unemployment rate in Ukraine is the same as in EU $-7.3 \%$. For example, in Poland, where massive amount of Ukrainians went to work, the percentage of unemployed is $13 \%$ of the economically active population.

Ukraine is at about half or two thirds of the European Union in terms of public R\&D expenditures, innovation expenditures, employment in medium to high-tech manufacturing and hightech services. The positive or at least moderate performance in these indicators is in stark contrast to the level of broadband penetration, business R\&D expenditures, public funding of innovations and high-tech exports (European Innovation Scoreboard, 2009).

The study of the labour market in Ukraine highlights the growing discrepancy between skilled and unskilled labour force. Denisova (Denisova, 2005) estimated the wage gap between skilled and unskilled workers at 20 percent in 1991-2001. Among observable explanations, education has the largest explanatory power: it accounted for 20-30 percent of the wage gap in 1995 and 50 percent in 2002. Additionally, employment in manufacturing industries, except the metals industry, tends to increase the wage gap, albeit modestly.

Gianella, Tompson (Gianella \& Tompson, 2007) find out that market concentration has a negative and highly significant impact on labor productivity growth: a one percentage point decline in the Herfindahl-Hirschmann indexes is associated with an increase in labor productivity growth of 0.2 $0.3 \%$. Authors assert that high levels of market concentration and weak competition are partly a product of Ukraine's inherited economic structure, but they are also, in large measure, the result of misguided policies.

The infrastructure developments, investment in education, job training and retraining programs have significant impact on country's social performance. Ukraine is ranked 71 among 190 economies in the ease of doing business, according to the latest World Bank annual ratings. The rank of Ukraine improved to 71 in 2018 from 76 in 2017. Ease of Doing Business in Ukraine averaged 112.36 from 2008 until 2018, reaching an all-time high of 152 in 2011 and a record low of 71 in 2018 (Ease of Doing Business in Ukraine, 2019). The existing trade-off between the needs for technological upgrading and regulatory reform make priority task creation attractive business environment. Regulatory reforms should be prioritized in precisely those areas with potential for medium and longterm growth. The aim would be to remove sector specific, institutional obstacles to growth without creating new distortions. This would require addressing failures in inadequate training and investment in human capital in these areas, as well as designing technology-, sector- or area-specific 
investment promotion packages with due care not to give unfair advantages to specific types of investors. A challenge for Ukrainian policymakers is to balance horizontal and vertical regulatory reforms, as well as balancing horizontal with technology-specific innovation policy programmes. The complementary character for regulatory reforms and innovation policy measures directs toward speeding economic reforms in Ukraine. The system of technical regulations hinders modernization through its complexity, lack of self-regulation, obsolescence and huge scope for administrative discretion (Innovation Performance Review of Ukraine, 2013).

The main factors contributing to the growth of total factor productivity are structural reforms in the economy, as well as a decrease in the share of the shadow economy. The labor market reform includes the liberalization of labor legislation which expands employment and creates more jobs. Labor Code should regulate narrow section of the relationship between employer and employee and provide balance the interests of employers and employees (Nosova, 2018). The current labour policy directs promoting the employment; presenting assistance in educating or retraining; stimulating the creation of a flexible labor market. The priorities of reforming the Ukrainian labor market are: improving the wage system; the expansion of opportunities for the public to get official, basic and additional-income; social support of certain groups; improving the quality and competitiveness of the labor force; promoting effective and reasonable movement of the labor force; preventing the growth of unemployment by creating jobs through various sources of funding; implementation of release and redistribution mechanisms; restructuring of the economy and rising domestic production.

According to the assessment of the Top-10 innovative countries ranking by the Bloomberg Innovation Index 2019 Ukraine takes $53^{\text {th }}$ place (table 1) in 2019 comparing to $46^{\text {th }}$ place in 2018.

Table 1

The Ranking of the Top-10 Innovative Countries by the Bloomberg Innovation Index in 2019

\begin{tabular}{|c|c|c|c|c|c|c|c|c|c|}
\hline $\begin{array}{c}\text { Rating } \\
\text { place } \\
\text { (Dynamics } \\
\text { comparing } \\
\text { with } \\
\text { previous } \\
\text { year) }\end{array}$ & Country & 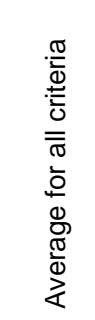 & 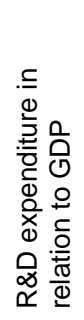 & $\begin{array}{l}\bar{D} \\
\frac{0}{0} \\
\frac{\pi}{0} \\
\frac{0}{0} \\
\frac{D}{\pi}\end{array}$ & 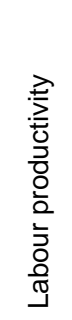 & 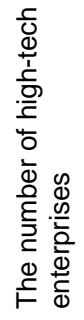 & 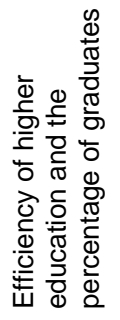 & 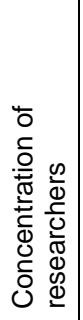 & 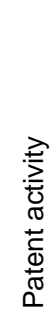 \\
\hline $1(0)$ & South Korea & 87,38 & 2 & 2 & 18 & 4 & 7 & 7 & 20 \\
\hline $2(+2)$ & Germany & 87,30 & 7 & 3 & 24 & 3 & 14 & 11 & 7 \\
\hline $3(+4)$ & Finland & 85,57 & 9 & 16 & 5 & 13 & 9 & 8 & 5 \\
\hline $4(+1)$ & Switzerland & 85,49 & 3 & 4 & 7 & 8 & 13 & 3 & 27 \\
\hline $5(+5)$ & Israel & 84,78 & 1 & 33 & 8 & 5 & 36 & 2 & 4 \\
\hline $6(-3)$ & Singapore & 84,49 & 13 & 5 & 11 & 17 & 1 & 13 & 14 \\
\hline $6(-3)$ & Sweden & 84,15 & 4 & 15 & 9 & 6 & 20 & 5 & 25 \\
\hline $8(+3)$ & USA & 83,21 & 10 & 25 & 6 & 1 & 43 & 28 & 1 \\
\hline $9(-3)$ & Japan & 81,96 & 5 & 7 & 22 & 10 & 39 & 18 & 10 \\
\hline $10(-1)$ & France & 81,86 & 12 & 41 & 13 & 2 & 11 & 20 & 15 \\
\hline $53(-7)$ & Ukraine & 48,5 & 54 & 58 & 60 & 37 & 28 & 46 & 35 \\
\hline
\end{tabular}

Source: Bloomberg Innovation Index 2019. (Viens, 2019)

Country is worsening position in the labour productivity to 60 th place comparing 50 th place in 2018. Ukraine was the worst in labour productivity which shows low level of applied technologies and production of goods with low added value, has got to three outsiders on technological possibilities (58th place) and takes 54th place in the level of expenses for research and development in gross domestic product. At the same time, it holds the 28 th place in higher education efficiency and 35 th in 
patent activity, meaning it has the potential for development. Ukraine is continuing provide efficient higher education and provide qualified graduates for the labour market.

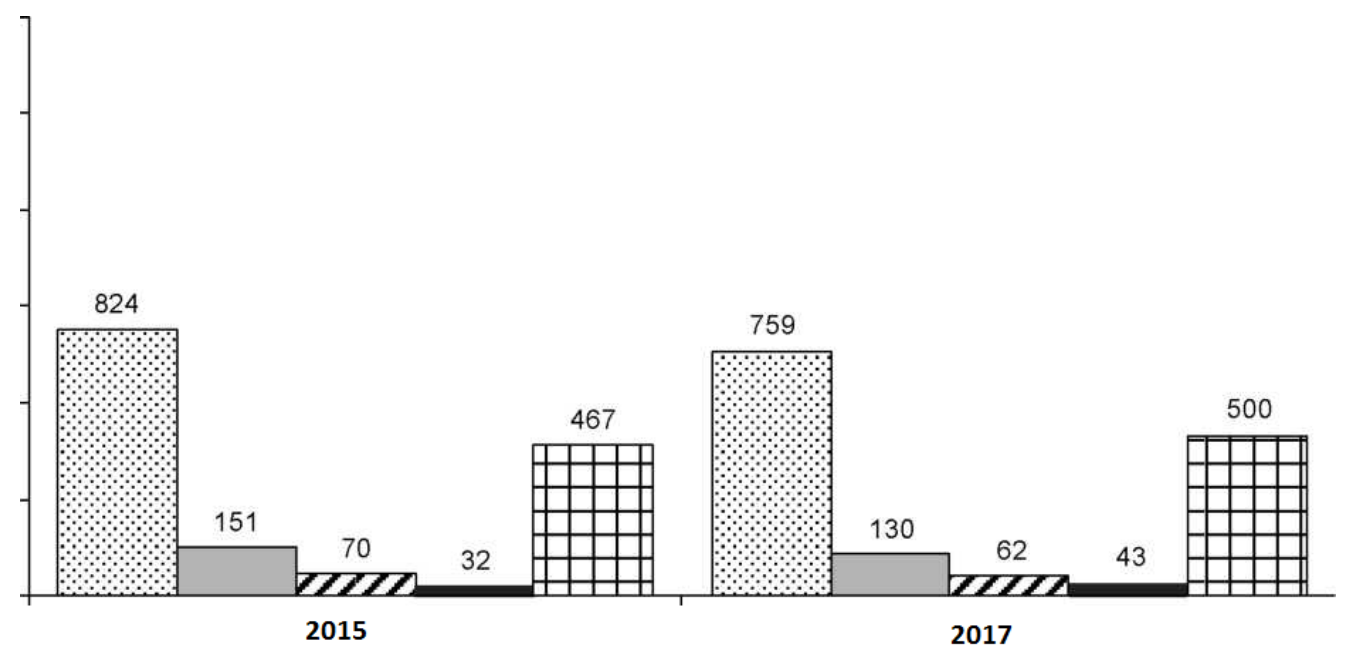

Fig. 1. Innovation Activity of Industrial Enterprises in Ukraine in 2015 and 2017 (number)

Source: (State Statistics Service of Ukraine, 2019)

The data figure 1 demonstrates that the industrial enterprises continue provide policy for enhancing innovation activity in Ukraine. Despite the fact that some indicators of innovation activity decrease, we can mark the positive trend in innovation development. The number of industrial enterprises providing innovation activity decreases from 824 in 2015 to 759 in 2017 in Ukraine, spent money for internal R\&D falls from 151 to 130 , spent money for external R\&D drops from 70 to 62 . Encouraging trend demonstrates that the spent money on the acquisition of other external knowledge increases from 32 to 43 , and spent money for buying machines, equipment and software rises from 467 to 500 .

According to the State Statistics Service data, in 2017, the IT sector accounted for more than 3 percent of gross domestic product, and the industry's total revenue exceeded $\$ 3.5$ billion, which is comparable to the high-tech sector output. A comprehensive new report into the Ukrainian IT industry produced by tech service provider $\mathrm{N}$-iX estimates that IT industry currently accounts for 20 $\%$ of Ukraine's overall service sector exports. The sector is growing an annual rate of $26 \%$, with approximately at 4000 IT companies active in the country. Ukraine is currently home to over 100 international research and development centers and counting, while there are an estimated 2000 startup companies. The Ukrainian IT industry is currently growing at a rate of approximately 30, 000 specialists workplaces per graduates with necessary skills to feel these vacancies, whereas the country's universities and institutes of higher education are only producing 16,000 (Ukraine IT Industry Overview, 2019).

Firm-level surveys show that more than 20 percent of firms in many developing countries rate inadequate skills and education of workers as a major or severe obstacle to their operations. Regulation of labour markets is usually intended to help workers, but can also be a significant constraint on firms (World Development Report, 2005).

Saha (Saha, 2015) argues that one attractive option can be the establishment of "cluster councils" for successful business clusters. These councils require little government involvement and not only help to improve communication between companies and government, but also magnify the visibility of success stories to potential investors. Rusnak and Prokhorchuk (Rusnak \& Prokhorchuk, 2018) propose specific initiatives to accelerate the development and implementation of "innovation laws"; to review the list and content of the existing scientific and technical programs with the purpose of more consideration of the world tendencies and their adaptation to the needs of the national economy; to develop an innovation monitoring system. 


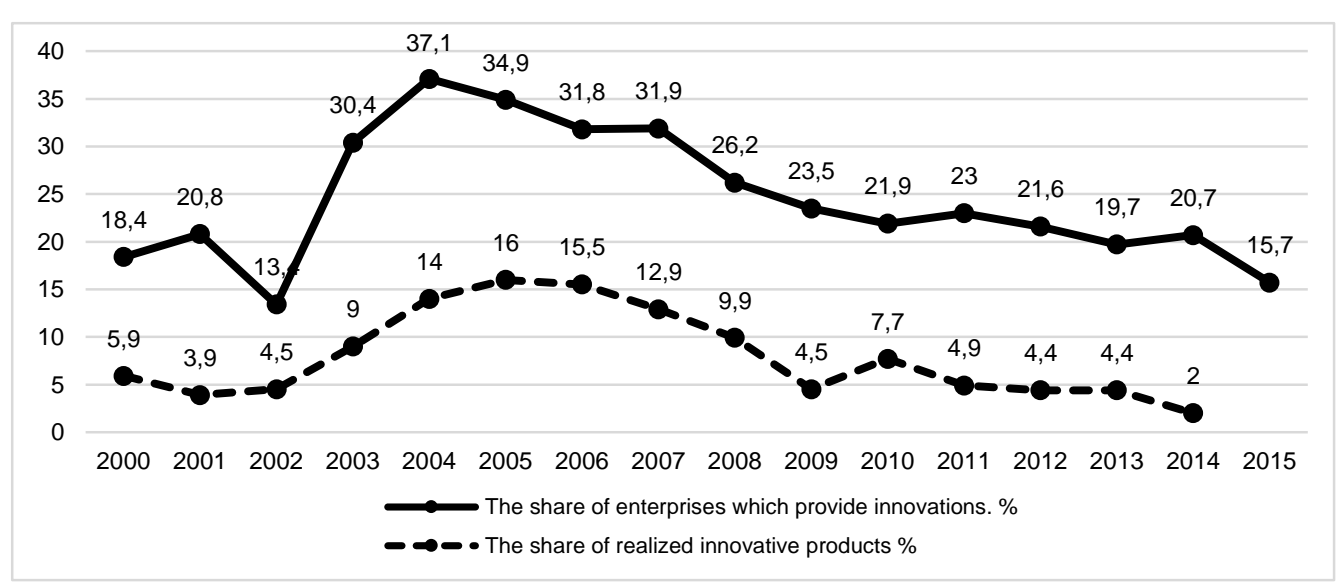

Fig. 2. Development of innovative processes in the volume of industry (\%)

Source: (State Statistics Service of Ukraine, 2019)

The market situation remains tense and is characterized by a decrease in demand for labor in Ukraine. The main trends in the labor market could be defined by extremely low employment rate. The employment rate is $56.9 \%$, including $57.6 \%$ in urban areas and $55.5 \%$ in rural. Employment rates among men were higher than among women $-62.5 \%$ and $51.9 \%$ respectively. Despite depressed growth of unemployment, the unemployment rate remains high, especially among young people. Industrial production indices decrease to $87 \%$ in 2015 in comparison to $89.9 \%$ in previous year in Ukraine (Ukraine in figures 2016).

Muthusamy, Rasid (Muthusamy \& Rasid, 2018) propose managers to carry out an internal audit on existing internal training program and career development program for skilled employees. They consider these measures will help to improve managers ability to recruit, build skill and retain the skilled employees.

Innovation activities in Ukraine are largely financed from internal resources $(70 \%$ of innovative companies in 2011), although their share of total innovation expenditure has declined since 2005 (from $87.7 \%$ in 2005 to $52.9 \%$ in 2010). The share of state budgetary funds remains negligible, at around $1 \%$. The structure of innovation expenditure is dominated by the purchase of machinery, equipment and software (73\%), which contributes to technological catch-up. Internal R\&D expenditure represents $5.8 \%$, external R\&D and other knowledge inputs $2.3 \%$ and $1.7 \%$, respectively (UAH 246.6 million (Statistical Yearbook: Research and Innovation in Ukraine 2011, 2012). The structure of R\&D expenditure was industry specific (medium to medium-low technology and resource intensive sectors), with internal $R \& D$ activities concentrated in the machinery and chemical industries, and demand for external R\&D and other knowledge inputs in metallurgy and machine tools (Innovation Performance Review of Ukraine, 2013).

Some authors underline the main transformation in the world of work over the last 20 years in terms of the labour market, social dialogue, and conditions of work, wages and incomes, and effects on the middle class (Vaughan-Whitehead et al., 2016). Strong institutions are not only "the building blocks of just societies' but can be, if well designed, fully consistent with high employment and dynamic economies (Berg, 2015). The information technologies contribute into the average annual growth of labour productivity in a range of countries. The impact of IT on the system transformation of social labour relations defines by a set of parameters (Grishnova \& Kostenko, 2014).

The UNIDO assessment of the Competitive Industrial Performance in 2018 Ukraine is ranked $64^{\text {th }}$ with score 0,0407 among 150 countries. (Ukraine Competitiveness Rank, 2019) Ukraine enters the group of emerging industrial economies. Attraction inflow of new technologies and their dissemination lead to labour productivity increase per capita, and country's competitiveness improvement. The diffusion of advanced technologies support an increase in country's competitiveness. Technological diffusion contributes to greater competitiveness in manufacturing, the country's institutions, infrastructure, human capital, business environment and other factors must also be conducive to structural change (Rodrik, 2018). Government policy supporting education and 
retraining programs affects the prospects for individuals - and the ability of firms to enter new markets and adopts new technologies. It also needs to facilitate allocation of labor to its most productive use while helping workers cope with labor mobility. Technological progress that leads to higher productivity and economic growth improves working conditions and wages, but it can also result in more rapid changes to firms and industries. Improving the business climate goes hand in hand with enhancing human capital. A skilled workforce is essential for firms to adopt new and more productive technologies, and a better business environment raises the returns for investment in education. As firms have more opportunities and better access to new technologies, they demand more skilled workers and have stronger incentives to engage in growth-enhancing activities, raising both the private and social returns to education. Technology transfers by multinational firms, and technology adoptions by local firms, require a minimum of human capital and training. New technologies generally require significant organizational changes, which are also handled better by a skilled workforce. Firm's strategy directs towards workers' motivation, new jobs creation, labour efficiency increase and etc. Business regulations improvement can reduce incentives to make new investments, adjust the organization of work to take advantage of new technologies or opportunities, or hire more workers.

Conclusion. Regulatory barriers to growing business of any size continue to impede development of competition, entrepreneurship, and productivity increase. The sufficient state policy creates opportunities to improve countries position via the role of competition in spurring innovations. Efficient allocation of resources aims the adoption of micro and macro-economic measures for labor productivity per capita increase, market efficiency and technical efficiency improvement. The new technologies inflow and labor force education and training, will create the basis for innovation breakthrough to the informational society. Lasting a long time growth could be achieved on the basis of elaboration and application of innovations in all spheres of production. Highlighting the priority tasks of economic policy the top-priority investment in R\&D and in education, informational network improvement, reduction of labor shedding share in total labour productivity, provide regulatory reform, remove sector specific, institutional obstacles to growth, stimulate transparency and competitiveness for business.

The factors of labour productivity increase are the following: the quality of labour and socialeconomic conditions for workers, the level technical equipment, and the quality of labour organization. The basic characteristics of the labour costs are the level of qualification, professional knowledge, skills, competences, responsibility, working experience. Modernization of equipment, new kinds of technique use, the efficient resource technologies make up the fundament for stable development of country. The improvement of labour organization includes the application of new progressive forms of management.

\section{References}

1. Lundwall, B. (2007). National innovation systems - analytical concept and development tool. Journal Industry and Innovation, 14, 1, 95-119.

2. Bathelt, H., Cohendet, P., \& Henn, S. (2017). The Elgar companion to innovation and knowledge creation. Edward Elgar Publishing.

3. Fagerberg, J. (2007). Mission (im)possible? The role of innovation (and innovation policy) in supporting structural change \& sustainability transitions. Working Papers on Innovation Studies 20180216. Centre for Technology, Innovation and Culture, University of Oslo. Retrieved from https://ideas.repec.org/p/tik/inowpp/20180216.html.

4. Kulikov, G. (2008). Ways To Regulate Wages in Ukraine. Labor and wages, 29, 4-6.

5. Bogliacino, F., Pianta, M. (2009). The Impact of Innovation on Labour Productivity Growth in European Industries: Does It depend on Firm's Competitiveness Strategies? IPTS Working Paper on Corporate R\&D and Innovation, No. 13. Retrieved from https://pdfs.semanticscholar.org/59fa/2a5a07c703186ecdc4a949a88b0988ece507.pdf.

6. Preenen, P. T. Y., Vergeer, R. A., Kraan, K. O., \& Dhondt, S. (2015). Labour productivity and innovation performance: The importance of internal labour flexibility practices. Economic and Industrial Democracy. doi: $10.1177 / 0143831 \times 15572836$.

7. Dykha, M., Tanasiienko, N. and. Kolisnyk, G. (2017). Ensuring of Labor productivity growth in the context of investment and innovation activity intensification. Problems and Perspectives in Management, 15(4), 197-208.

8. Majcen, B., Radosevic, S., Rojec, M. (2009), Nature and Determinants of Productivity Growth of Foreign Subsidiaries in Central and East European Countries. Economic Systems, 33(2), 168-184. 
9. Matteo, C., Simone, G., Mancuso, P. (2012). ICT Capital and Labour Productivity Growth: A NonParametric Analysis of 14 OECD Countries. Retrieved from https://mpra.ub.uni-muenchen.de/68642/.

10. Vaughan-Whitehead, D., Rosalia Vazquez-Alvarez, R., Maître, N. (2016). Is the world of work behind middle-class erosion? DOI: $10.4337 / 9781786430601.00006$.

11. Berg, J. (ed.) (2015). Labour Markets, Institutions and Inequality: Building just societies in the 21 st century. Retrieved from https://www.elgaronline.com/view/edcoll/9781784712099/9781784712099.xml.

12. Grishnova, O., Kostenko, T. (2014). Information technologies within the system of novel factors of labour productivity growth: trends and paradoxes. Current Economic Problems, 2 (152), 462-468.

13. Economic Activity of Population in Ukraine 2018 (2019). Retrieved from https://ukrstat.org/en/druk/publicat/kat e/2019/zb/zb Ifs 2018.pdf.

14. European Innovation Scoreboard (2009). Comparative Analysis of Innovation Performance. (2009). Retrieved from http://www.proinno-europe.eu/metrics.

15. Denisova, A. (2005). Modern problems of system analysis. Informational basics. SPb. Publishing House of the Polytechnic University. (in Russian)

16. Gianella, C., Tompson, W. (2007). Closing the Productivity Gap in Ukraine. Further privatization and competition enhancing reform will stimulate greater dynamism. OECD Economies Department Working Papers. [Online], No.57. Retrieved from http://www.oecd.org.

17. Ease of Doing Business in Ukraine. (2019). Retrieved from https://tradingeconomics.com>Ukraine.

18. Innovation Performance Review of Ukraine. (2013). Retrieved from https://www.unece.org/fileadmin/DAM/ceci/publications/icp7.pdf.

19. Nosova, O. (2018). Economic modeling of regional development in Ukraine. Mind Journal, 6, 1-18. Retrieved from https://mindjournal.wseh.pl/ru/articles/nomer-62018.html.

20. Viens, A. (2019). The 10 most innovative Economies in 2019. Which countries snag this year's top spots, and how much are they investing in R\&D? The World's Most Innovative Economies. Retrieved from https://www.visualcapitalist.com/the-10-most-innovative-economies-in-2019/.

21. State Statistics Service of Ukraine. Retrieved from http://ukrstat.gov.ua.

22. Ukraine IT industry overview. (2019). Retrieved from https://outsourcingreview.org/outsourcingplaybook/it-industry-overview/.

23. World Development Report. (2005). Retrieved from http://siteresources.worldbank.org/INTWDR2005/Resources/complete report.pdf.

24. Saha, D., Kravchuk, V. (2015). The Industrial Sector of Ukraine: Trends, Challenges and Policy Options. Retrieved from http://www.beratergruppe-ukraine.de.

25. Rusnak, A., Prokhorchuk, S. (2018). Innovative Capacity of Ukraine's Economy in the International Context. Baltic Journal of Economic Studies, 4, 3. Retrieved from https://doi.org/10.30525/2256-0742/2018-4-3264-270.

26. Muthusamy, V., Abdul Rasid, S.Z. (2018). Leveraging Human Capital Development for Sucessful Labour Mix Rationalizatioin and Productivity Growth. International Journal of Innovation and Business Strategy (IJIBS). University Technology Malaysia, 10, 2, 46-58.

27. Statistical Yearbook: Research and Innovation in Ukraine 2011 (2012). Retrieved from http://www.ukrstat.gov.ua/.

28. Competitive Industrial Performance Report 2018. (2019). Retrieved from https://www.unido.org/sites/default/files/files/2019-05/CIP Report 2019.pdf.
29. Ukraine Competitiveness Rank.
(2019).
Retrieved
from https://tradingeconomics.com/ukraine/competitiveness-rank. 73-90.

30. Rodrik, D. (2018). What Do Trade Agreements Really Do? Journal of Economic Perspectives, 32, 2 ,

\section{Література}

1. Lundwall B. National innovation systems - analytical concept and development tool. Journal Industry and Innovation. 2007. Vol. 14. Issue 1. P. 95-119.

2. Bathelt $\mathrm{H}$., Cohendet P., Henn, S. The Elgar companion to innovation and knowledge creation. Edward Elgar Publishing. 2017. 840 p.

3. Fagerberg J. Mission (im)possible? The role of innovation (and innovation policy) in supporting structural change \& sustainability transitions. Working Papers on Innovation Studies. Centre for Technology, Innovation and Culture, University of Oslo. 2007. URL: https://ideas.repec.org/p/tik/inowpp/20180216.html.

4. Kulikov G.T. Ways To Regulate Wages in Ukraine. Labor and wages. 2008. №29. P. 4-6.

5. Bogliacino F., Pianta M. The Impact of Innovation on Labour Productivity Growth in European Industries: Does It depend on Firm's Competitiveness Strategies? IPTS Working Paper on Corporate R\&D and Innovation. 2009. No. 13. URL:https://pdfs.semanticscholar.org/59fa/2a5a07c703186ecdc4a949a88b0988ece507.pdf.

6. Preenen, P. T. Y., Vergeer, R. A., Kraan, K. O., \& Dhondt, S. (2015). Labour productivity and innovation performance: The importance of internal labour flexibility practices. Economic and Industrial Democracy. doi: $10.1177 / 0143831$ X15572836. 
7. Dykha M.V., Tanasiienko N.P. and. Kolisnyk G.M. Ensuring of Labor productivity growth in the context of investment and innovation activity intensification. Problems and Perspectives in Management. 2017. Vol.15(4). P. 197-208.

8. Majcen B., Radosevic S., Rojec M. Nature and Determinants of Productivity Growth of Foreign Subsidiaries in Central and East European Countries. Economic Systems. 2009. Vol. 33(2). P.168-184.

9. Matteo C., Simone G., Mancuso P. ICT Capital and Labour Productivity Growth: A Non-Parametric Analysis of 14 OECD Countries.2012. URL: https://mpra.ub.uni-muenchen.de/68642/.

10. Vaughan-Whitehead D., Rosalia Vazquez-Alvarez R., Maître N. Is the world of work behind middleclass erosion? 2016. DOI: 10.4337/9781786430601.00006.

11. Berg, J. (ed.) Labour Markets, Institutions and Inequality: Building just societies in the 21st century. 2015. URL: https://www.elgaronline.com/view/edcoll/9781784712099/9781784712099.xml.

12. Grishnova O., Kostenko T. Information technologies within the system of novel factors of labour productivity growth: trends and paradoxes. Current Economic Problems. 2014. No.2 (152). C. 462-468.

13. Economic Activity of Population in Ukraine 2018 (2019). URL: https://ukrstat.org/en/druk/publicat/kat e/2019/zb/zb Ifs 2018.pdf.

14. European Innovation Scoreboard, 2009. Comparative Analysis of Innovation Performance. 2009. URL: http://www.proinno-europe.eu/metrics.

15. Денисова А.А. Современные проблемы системного анализа. Информационные основы. СПб. Изд-во Политехнического университета. 2005. 296 с.

16. Gianella C., Tompson W. Closing the Productivity Gap in Ukraine. Further privatization and competition enhancing reform will stimulate greater dynamism. OECD Economies Department Working Papers. 2007. No.57. URL: http://www.oecd.org.

17. Ease of Doing Business in Ukraine, 2019 Ease of Doing Business in Ukraine. 2019. URL: https://tradingeconomics.com>Ukraine.

18. Innovation Performance Review of Ukraine. (2013). URL: https://www.unece.org/fileadmin/DAM/ceci/publications/icp7.pdf.

19. Nosova O.V.Economic modeling of regional development in Ukraine. Mind Journal. Semiannual.- No 6Bielsko-Biala, 2018. P. 1-18. URL: https://mindjournal.wseh.pl/ru/articles/nomer-62018.html.

20. Viens A. The 10 most innovative Economies in 2019. Which countries snag this year's top spots, and how much are they investing in R\&D? The World's Most Innovative Economies. 2019. URL: https://www.visualcapitalist.com/the-10-most-innovative-economies-in-2019/.

21. Державна служба статистики України. URL: http://ukrstat.gov.ua.

22. Ukraine IT industry overview. 2019. URL: https://outsourcingreview.org/outsourcing-playbook/itindustry-overview/.

23. World Development Report. 2005. URL: http://siteresources.worldbank.org/INTWDR2005/Resources/complete report.pdf.

24. Saha D., Kravchuk V. Policy Paper. The Industrial Sector of Ukraine: Trends, Challenges and Policy Options. 2015. URL: http://www.beratergruppe-ukraine.de

25. Rusnak A., Prokhorchuk S. Innovative Capacity of Ukraine's Economy in the International Context. Baltic Journal of Economic Studies. 2018. Vol. 4, No. 3. URL: https://doi.org/10.30525/2256-0742/2018-4-3-264-270. 26. Muthusamy V., Abdul Rasid S.Z. Leveraging Human Capital Development for Sucessful Labour Mix Rationalization and Productivity Growth. International Journal of Innovation and Business Strategy (IJIBS). University Technology Malaysia. 2018. Vol. 10. No. 2. P. 46-58.

27. Statistical Yearbook: Research and Innovation in Ukraine 2011. 2012. URL: http://www.ukrstat.gov.ua/. 28. Competitive Industrial Performance Report 2018. 2019. URL: https://www.unido.org/sites/default/files/files/201905/CIP Report 2019.pdf.

29. Ukraine Competitiveness Rank. 2019. URL: https://tradingeconomics.com/ukraine/competitiveness-rank.

30. Rodrik D. What Do Trade Agreements Really Do? Journal of Economic Perspectives. 2018. Vol. 32, No. 2. P.73-90. 